\title{
Occupational injuries and diseases in fish farming in Finland 1996-2015
}

\author{
Kim Olavi Kaustell ${ }^{1}$, Tiina Elina Anneli Mattila ${ }^{1}$, Anssi Ahvonen $^{1}$, Risto Heikki Rautiainen ${ }^{2}$ \\ ${ }^{1}$ Natural Resources Institute Finland (Luke), Helsinki, Finland \\ ${ }^{2}$ University of Nebraska Medical Centre, Omaha, NE, USA
}

\begin{abstract}
Background: The agriculture, forestry and fishing industry sector has high rates of occupational injuries. Fishing has globally particularly high occupational fatality rates, but injuries and illnesses to people working in its sub-sectors, aquaculture and fish farming, are not well understood.

Materials and methods: This study characterised injuries and occupational diseases to fish farmers and people employed on fish farms in Finland using national employment and accident insurance (workers' compensation) data.

Results: A total of 392 injuries and 18 occupational diseases were compensated during 1996 to 2015 to fish farmers and people employed on fish farms in Finland. The average injury rate was 3.2 injuries per 100 employed persons with no significant trend over time. Two of the injuries were fatal. Injured persons were primarily male (87.2\%), in 45-54 year age group (39.1\%), and working in coastal areas (49\%). Common injury characteristics included: incident type: slips, trips, and falls (37\%); location: building, structure or ground level surface (28\%); injured body part: hand or finger (25\%); type of injury: dislocation, sprain, strain (35\%); and lost worktime: 1 to 2 weeks (26.9\%). Seven out of 18 occupational diseases occurred to women, most resulting in cumulative trauma from fish processing.

Conclusions: The injury rate in fish farming corresponds to rate in all industries combined in Finland, and is higher than the rate in available Nordic statistics on fish farming. Fish farming injuries could be reduced further by slip resistant surfaces, protection of hands and fingers and ergonomics in processing.
\end{abstract}

(Int Marit Health 2019; 70, 1: 47-54)

Key words: aquaculture, occupational injuries, occupational diseases

\section{INTRODUCTION}

In 2015, there were 430 fish farms in Finland; out of which $29 \%$ in sea areas. During the period 1996-2015, the number of fish farms decreased as shown in Figure 1, and the quantity of food fish production decreased from 17.7 million $\mathrm{kg}$ in 1996 to 14.9 million kg in 2015. The production level remained at about that level through 2017 [1]. Food fish is mainly cultivated in sea areas while most of the fry are cultivated on inland fry farms and natural food ponds. The fry from natural ponds are used primarily for fish restocking.

In spite of declining production quantities, the total value of food fish production has grown remarkably in recent years; from 55.6 million euros in 2015 to 79.8 million euros in 2017 , mainly due to higher average producer prices for rainbow trout, which is the main product of Finnish food fish farms.

Domestic food fish production (14.6 million kg in 2017) covers about one third of the consumption in Finland. The national target is that the volume of aquaculture production exceeds 20 million $\mathrm{kg}$ and 100 million euros by 2020 in mainland Finland, while ensuring ecologic, economic and social sustainability of the production at the same time [2]. The growth is expected to come from offshore and recirculation aquaculture systems (RAS). In both approaches, ecological and social sustainability can be well maintained, but there are significant economic challenges. Especially for RAS, the required initial investments are heavy, and also the running costs, especially 


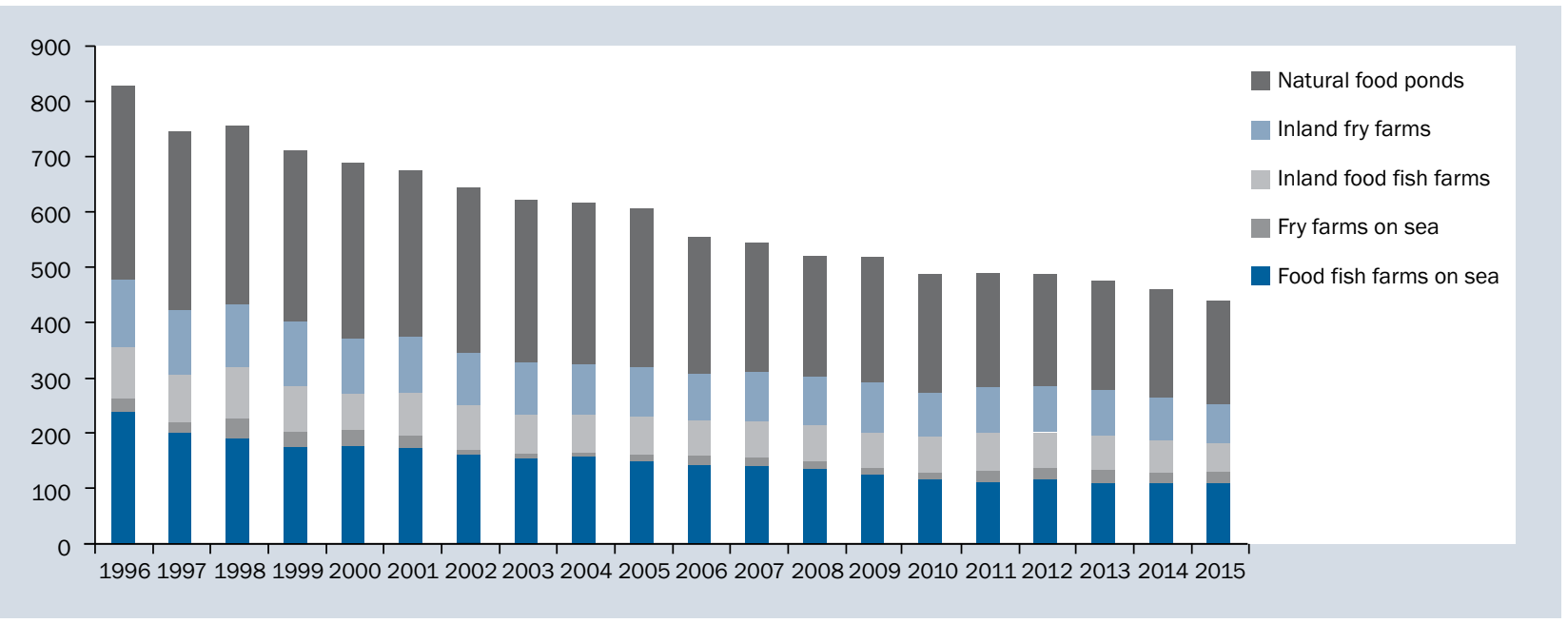

Figure 1. The number of fish farms in Finland during 1996-2015 [1]

energy, are high compared to conventional aquaculture in inland or sea operations.

New technologies may have new consequences for occupational safety. The working environment on RAS farms has characteristics from both intensive animal farming and processing industries. Although offshore fish farming will be automated as far as possible, there is still a need for human efforts at sea, often in rough weather conditions.

Occupational injuries on Finnish fish farms have not been studied in similar detail as e.g. in the construction or manufacturing industries, where the injury rates have decreased significantly in past decades. The aim of this study was to characterise occupational injuries and diseases in fish farming. This information may contribute to the development of safety communication and interventions, as well as to promoting social sustainability in the fish farming trade.

\section{MATERIALS AND METHODS}

Injury data used in this study were acquired from the Finnish Workers' Compensation Centre (TVK, www. tvk.fi/en/). TVK is a body that by law, among other responsibilities, compiles statistics on occupational injuries and diseases, including their characteristics and consequences. The data originate from insurance institutions that administer statutory occupational accident insurance policies in Finland.

Occupational injury and disease claims data were acquired for the years 1996-2015, using the Standard Industrial Classification (SIC) 2002 [3] codes "fish farming" for cases before 1999, and SIC 2008 [4] codes "fish farming on sea" and "fish farming on land/lakes" for cases since year 1999. The final data set comprised of 392 injuries that happened to 248 employees and 36 fish farm entrepreneurs. Two of the injury cases were fatal.
The insurance claims data were anonymised by TVK before providing access to the research team. The data comprised of demographic variables including age, gender, and nationality of the injured person, as well as incident information on the time, location, cause, deviation, injured body part, type of injury, task and activity, and a short legend (max. 300 characters) describing the incident. Additionally, compensation type, duration and amount, as well as number of days away from work were available.

Employment statistics [5] were used to estimate the number of employed persons (including both entrepreneurs and salaried workers) in the fish farming trade. These data were available as of year 2001. Injury rates could be calculated only for these years.

Due to changes and development in various data sources used in this study, some data were not available from the beginning of the study period. To simplify reporting, data analysis was performed on two data subsets: One with a "basic" set of variables for the whole period, 1996 to 2015 ( $n=392$ ), and another subset with an "extended set" of variables for the years 2003-2015 ( $n=196)$. The extended set comprised of additional European Statistics of Accidents at Work (ESAW)-conformant injury coding as well as employment and fish farm statistics.

Basic data were managed in Microsoft Office Excel 10. Further analysis as well as classifications and creation of compound variables were done in SAS Enterprise Guide version 7.13 [6].

\section{RESULTS}

The estimated fish farm worker population consisted of 520 fish farmers and persons employed on fish farms in 2001, decreasing to 396 in 2015. Employment data were not available for years 1996 through 2000. A total of 392 


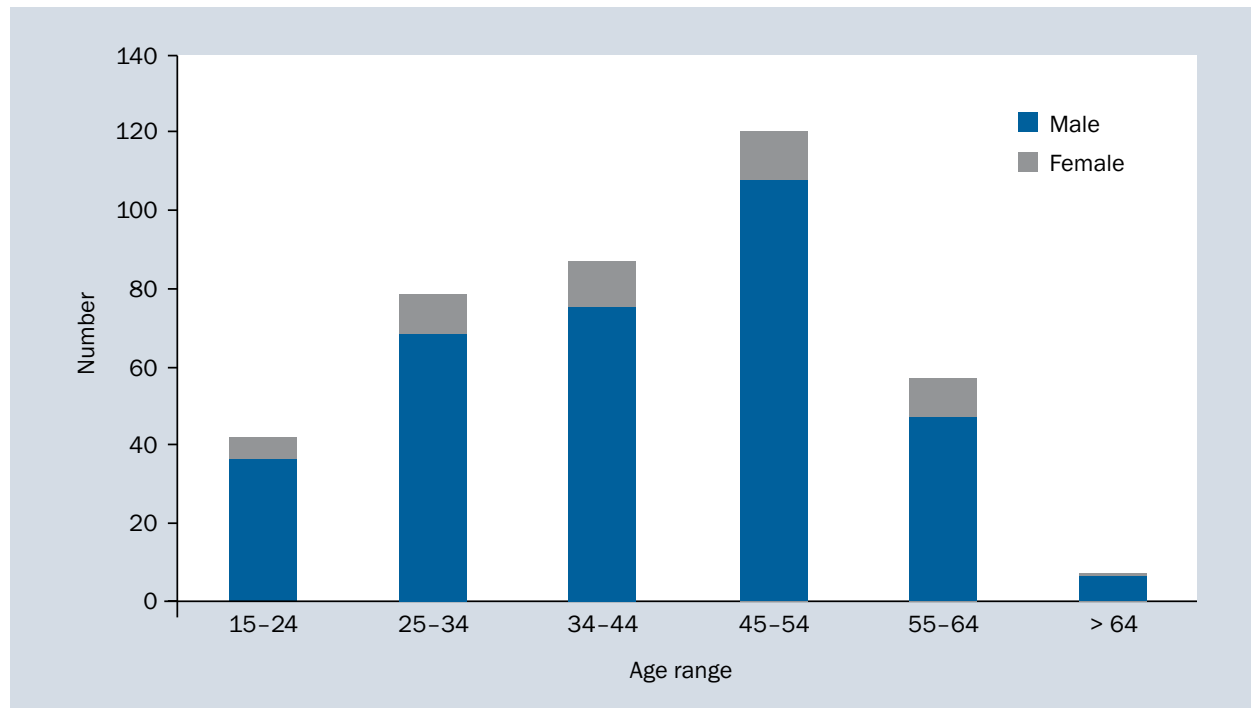

Figure 2. Number of injuries by age range and gender $(n=392)$

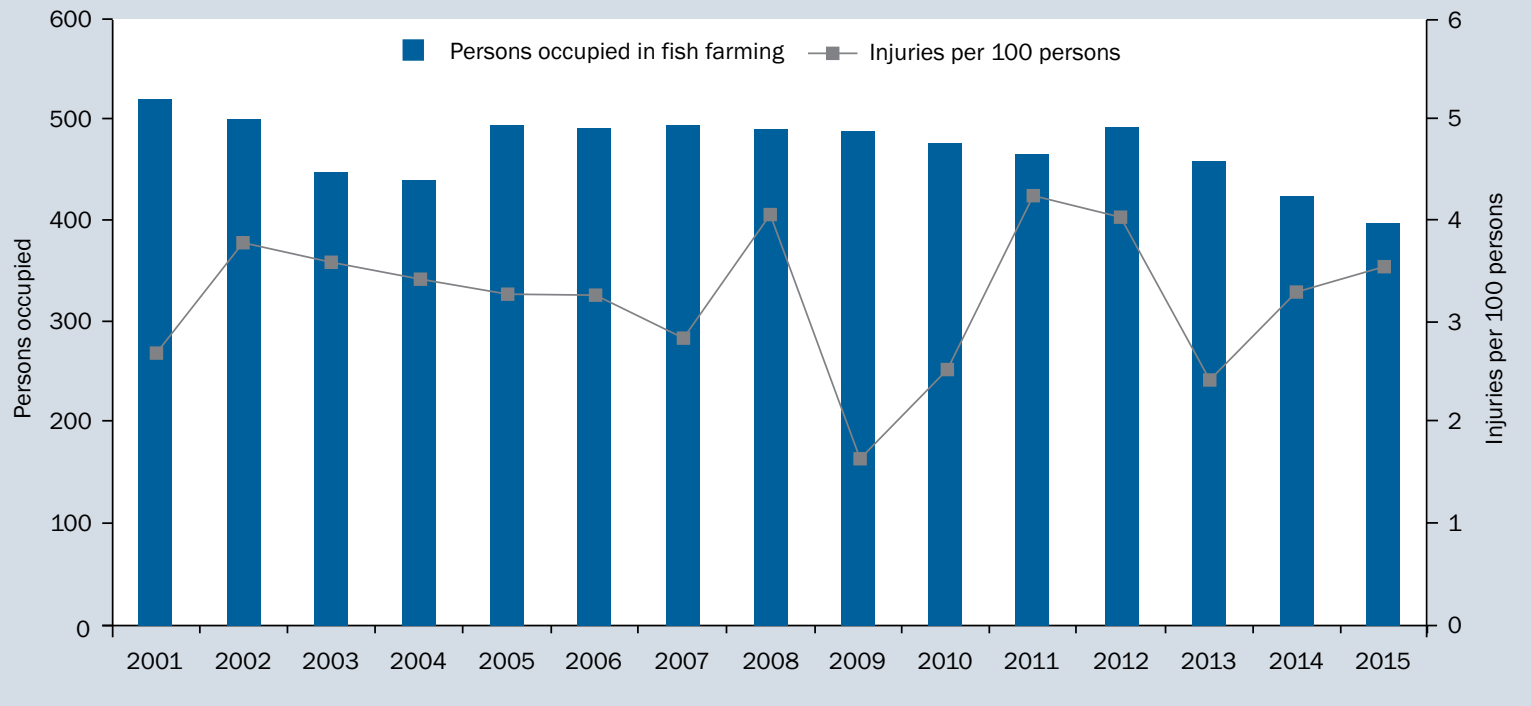

Figure 3. Annual number of persons occupied and injury rate in fish farming

injuries and 18 occupational diseases were compensated during 1996 to 2015 in the fish farming population. The median age of the injured persons was 44 years (mean 42 years), and $87.2 \%$ of the injured persons were male. There were no significant differences in gender distribution by age. The highest proportion of injuries (39.1\%) was found in the age group 45-54 years (Fig. 2).

The number of compensated injuries in fish farming varied around the mean of 18 per year with a range from 8 to 38 . Three out of four ( $n=231$ ) injured persons had only suffered one injury, while $18 \%(n=52)$ had two injuries during 1996 to 2015 , and the rest $(7 \%, n=19)$ had experienced three or more (up to 6) compensated injuries. Injured employees $(n=248)$ had suffered 1.3 injuries per person on average while injured fish farmers (entrepreneurs, $n=36$ ) had a corresponding mean of 1.8 .

The annual injury rate varied around the mean of 3.2 injuries per 100 persons occupied (all injuries included) as shown in Figure 3. No significant trend can be observed in the annual data. The corresponding mean rate for injuries with more than 3 days of lost working time is 2.1 .

Nearly half of the injuries (48.5\%, or 189 ) happened in coastal areas (Table 1). The number of fish farming facilities and injury ratios (injuries per mean number of facilities) are based on statistics of fish farming facilities for 
Table 1. Number of injuries, fish farming facilities, and injuries per facility by geographical region

\begin{tabular}{|c|c|c|c|c|c|}
\hline \multirow[t]{2}{*}{ Region } & \multicolumn{2}{|c|}{ Injuries* } & \multicolumn{2}{|c|}{ Facilities** } & \multirow{2}{*}{$\begin{array}{l}\text { Injuries } \\
\text { per facility }\end{array}$} \\
\hline & $\mathbf{N}$ & Per cent & $\mathbf{N}$ & Per cent & \\
\hline Coast & 189 & $48.5 \%$ & 109 & $51.4 \%$ & 1.7 \\
\hline Lake district & 88 & $22.6 \%$ & 24 & $11.3 \%$ & 3.6 \\
\hline Northern Finland & 71 & $18.2 \%$ & 44 & $20.8 \%$ & 1.6 \\
\hline Åland & 42 & $10.8 \%$ & 35 & $16.5 \%$ & 1.2 \\
\hline Total & 390 & $100 \%$ & 212 & $100 \%$ & \\
\hline
\end{tabular}

* Missing or not known $(\mathrm{n}=2)$

**The number of facilities is a mean for the years 1996-2015

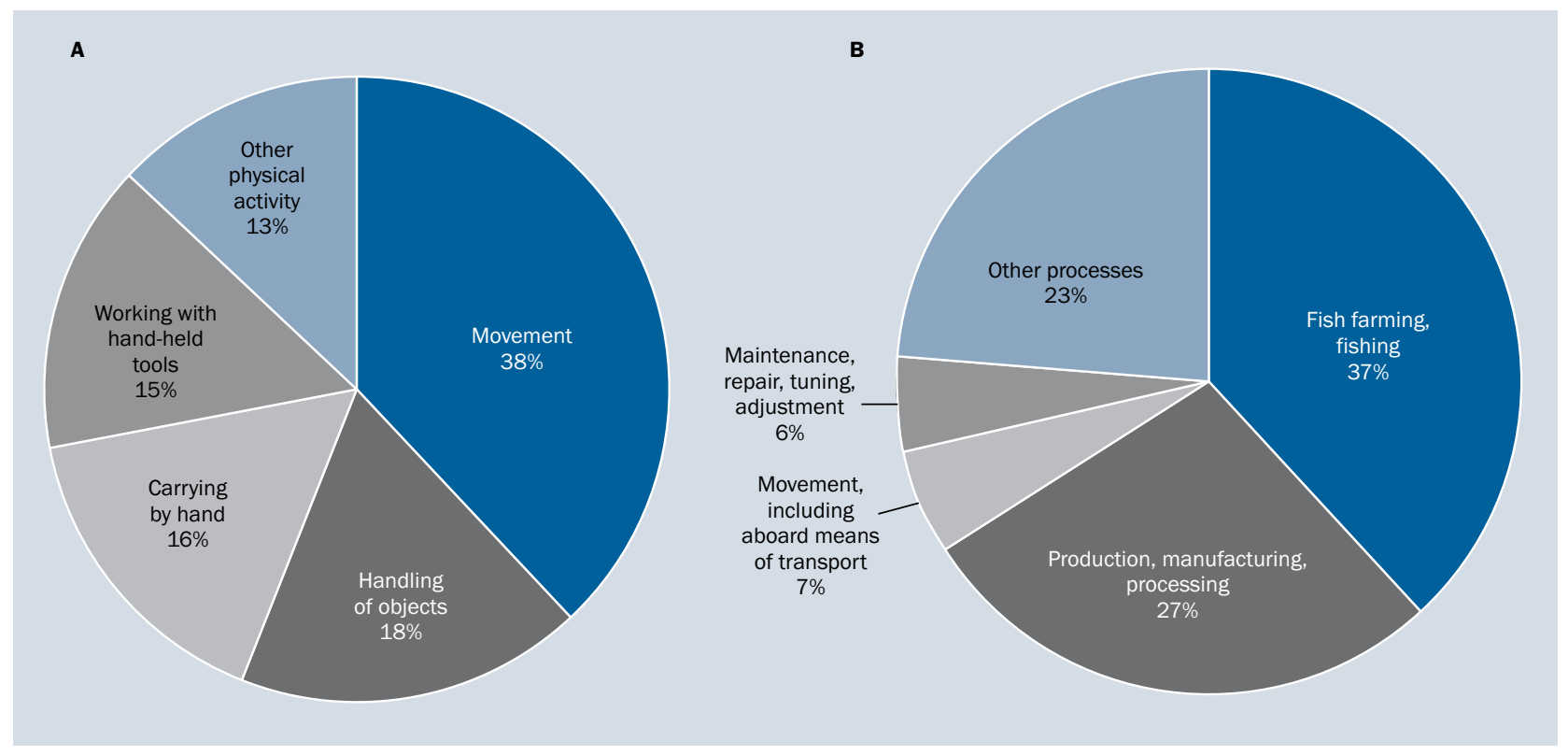

Figure 4. Specific physical activity (A) and working process during injury $(\mathbf{B})(n=196)$

1999-2015 and linearly extrapolated values for the years 1996-1998.

Information on the working process, as well as the specific physical activity at the time of injury was available only for injuries that happened between the years 2003-2015 $(n=196)$. In these data, most injuries happened when moving (the specific physical activity) either during actual fish farming or fishing (16\% or 31 injuries), or other production processes (11\% or 22 injuries) (Fig. 4A, B).

Typical case descriptions for corresponding combinations of a special physical activity and working process include the following: "The injured person was feeding the fish, slipped, fell over, and hit her head." and "The injured person was washing the facilities in a bent posture. When raising his position, he hurt his head against a tipping device."

More than one third of the injuries were the result of slipping, stumbling, and falling (Table 2). These events (deviations) resulted in a horizontal or vertical impact (Table 3)
Table 2. Deviations that lead to injuries

\begin{tabular}{|c|c|c|}
\hline Deviation & $\mathbf{N *}$ & Per cent \\
\hline Slipping, stumbling, and falling & 141 & $36.5 \%$ \\
\hline $\begin{array}{l}\text { Body movement without any } \\
\text { physical stress }\end{array}$ & 84 & $21.8 \%$ \\
\hline $\begin{array}{l}\text { Body movement under or with } \\
\text { physical stress }\end{array}$ & 48 & $12.4 \%$ \\
\hline Loss of control of machine, tool, or object & 44 & $11.4 \%$ \\
\hline Breakage, fall, or collapse of material agent & 28 & $7.3 \%$ \\
\hline $\begin{array}{l}\text { Overflow, overturn, leak, flow, } \\
\text { vaporisation, emission }\end{array}$ & 18 & $4.7 \%$ \\
\hline Other & 14 & $3.6 \%$ \\
\hline Electrical problems, explosion, fire & 8 & $2.1 \%$ \\
\hline $\begin{array}{l}\text { Shock, fright, violence, aggression, } \\
\text { threat, presence }\end{array}$ & 1 & $0.3 \%$ \\
\hline Total & 386 & $100 \%$ \\
\hline
\end{tabular}


Table 3. Contact modes of the injuries

\begin{tabular}{lll}
\hline Contact - mode of injury & N* & Per cent \\
\hline $\begin{array}{l}\text { Horizontal or vertical impact (the victim } \\
\text { is in motion) }\end{array}$ & 71 & $36.8 \%$ \\
$\begin{array}{l}\text { Physical or mental stress } \\
\begin{array}{l}\text { Contact with sharp, pointed, rough, coarse } \\
\text { material agent }\end{array}\end{array}$ & 28 & $14.5 \%$ \\
$\begin{array}{l}\text { Struck by, or collision with object in motion } \\
\text { Trapped, crushed, etc. }\end{array}$ & 20 & $10.4 \%$ \\
$\begin{array}{l}\text { Contact with hazardous substances } \\
\text { Other contacts (involving heat, and }\end{array}$ & 17 & $8.8 \%$ \\
human/animal interaction) & 10 & $5.2 \%$ \\
Total & 193 & $100 \%$ \\
*Missing or not known $(\mathrm{n}=3)$ & &
\end{tabular}

*Missing or not known $(n=3)$

Table 4. Material agents in injuries

\begin{tabular}{|c|c|c|}
\hline Material agent & $N *$ & Per cent \\
\hline $\begin{array}{l}\text { Buildings, structures, surfaces - at ground } \\
\text { level }\end{array}$ & 106 & $27.7 \%$ \\
\hline $\begin{array}{l}\text { Materials, objects, products, machine or } \\
\text { vehicle components, debris, dust, waste }\end{array}$ & 74 & $19.3 \%$ \\
\hline $\begin{array}{l}\text { Other material agents not listed in } \\
\text { this classification }\end{array}$ & 59 & $15.4 \%$ \\
\hline Hand tools, hand-guided tools & 40 & $10.4 \%$ \\
\hline $\begin{array}{l}\text { Conveying, transport, distribution and } \\
\text { storage systems, pipe networks }\end{array}$ & 25 & $6.5 \%$ \\
\hline $\begin{array}{l}\text { Buildings, structures, surfaces - above } \\
\text { or below ground level }\end{array}$ & 22 & $5.7 \%$ \\
\hline $\begin{array}{l}\text { Chemical, explosive, radioactive, biological } \\
\text { substances }\end{array}$ & 20 & $5.2 \%$ \\
\hline $\begin{array}{l}\text { Machines and equipment, fixed or } \\
\text { mobile/portable }\end{array}$ & 17 & $4.4 \%$ \\
\hline Land and other transport vehicles & 13 & $3.4 \%$ \\
\hline $\begin{array}{l}\text { Living organisms, human beings, physical } \\
\text { phenomena and natural elements }\end{array}$ & 7 & $1.8 \%$ \\
\hline Total & 383 & $100 \%$ \\
\hline
\end{tabular}

with or against a stationary object in $79.5 \%$ of the cases. Typical material agents (Table 4) in these cases include slippery ground or floor, as well as debris and various objects, on which the victims stumbled.

Hands and fingers were most frequently injured body parts (Table 5), typically resulting in wounds and superficial injuries ( $n=60$ or $62 \%$ ). Dislocations, sprains and strains were most frequent types of injuries (Table 6) affecting the back and spine, as well as arms and legs.

Dislocations, sprains, and strains had relatively severe consequences, two thirds of them (66\%) resulting in 1 to
Table 5. Part of body injured

\begin{tabular}{lll}
\hline Part of body injured & N* & Per cent \\
\hline Hand, finger & 97 & $24.9 \%$ \\
Leg from hip to ankle & 75 & $19.2 \%$ \\
Arm from shoulder to wrist & 63 & $16.2 \%$ \\
Back, spine & 37 & $9.5 \%$ \\
Eye & 32 & $8.2 \%$ \\
Head, excluding eyes & 26 & $6.7 \%$ \\
Foot and toes & 22 & $5.6 \%$ \\
Other, e.g. internal organ injury & 16 & $4.1 \%$ \\
Neck and body excluding back & 14 & $3.6 \%$ \\
Multiple body parts & 8 & $2.1 \%$ \\
Total & 390 & $100 \%$ \\
*Missing or not known $(n=2)$ & &
\end{tabular}

Table 6. Type of injury

\begin{tabular}{lll}
\hline Type of injury & N* & Per cent \\
\hline Dislocations, sprains and strains & 137 & $35.0 \%$ \\
Wounds and superficial injuries & 115 & $29.4 \%$ \\
Concussion and internal injuries & 69 & $17.6 \%$ \\
Bone fractures & 35 & $9.0 \%$ \\
Other (e.g. poisoning, suffocation) & 17 & $4.3 \%$ \\
Not known & 8 & $2.0 \%$ \\
Burns, scalds and frostbites & 7 & $1.8 \%$ \\
Traumatic amputations & 3 & $0.8 \%$ \\
Total & 391 & $100 \%$ \\
*Missing or not known $(n=1)$ & &
\end{tabular}

4 weeks of lost time. Wounds and superficial injuries were less severe, nearly two thirds (62\%) of them leading to up to 2 weeks of absence from work. The categorised numbers of days lost due to injury are presented in Figure 5. The statistics do not separate the number of injuries with no days lost in the 0-3 day category.

\section{FATALITIES}

The injury data included two fatalities in the fish farming industry during the years 1996-2015. Both happened to men (aged 49 and 59) in fish farming on sea. The material agent of the first causality was a conveyor or other transport or storage system, but no further injury details were available. The second causality has been investigated and reported by the Workers' Compensation Centre [7]. The victim was walking on newly frozen sea ice to check the winter basins between two islands. Despite thorough knowledge of local circumstances, over two decades of fish farming 


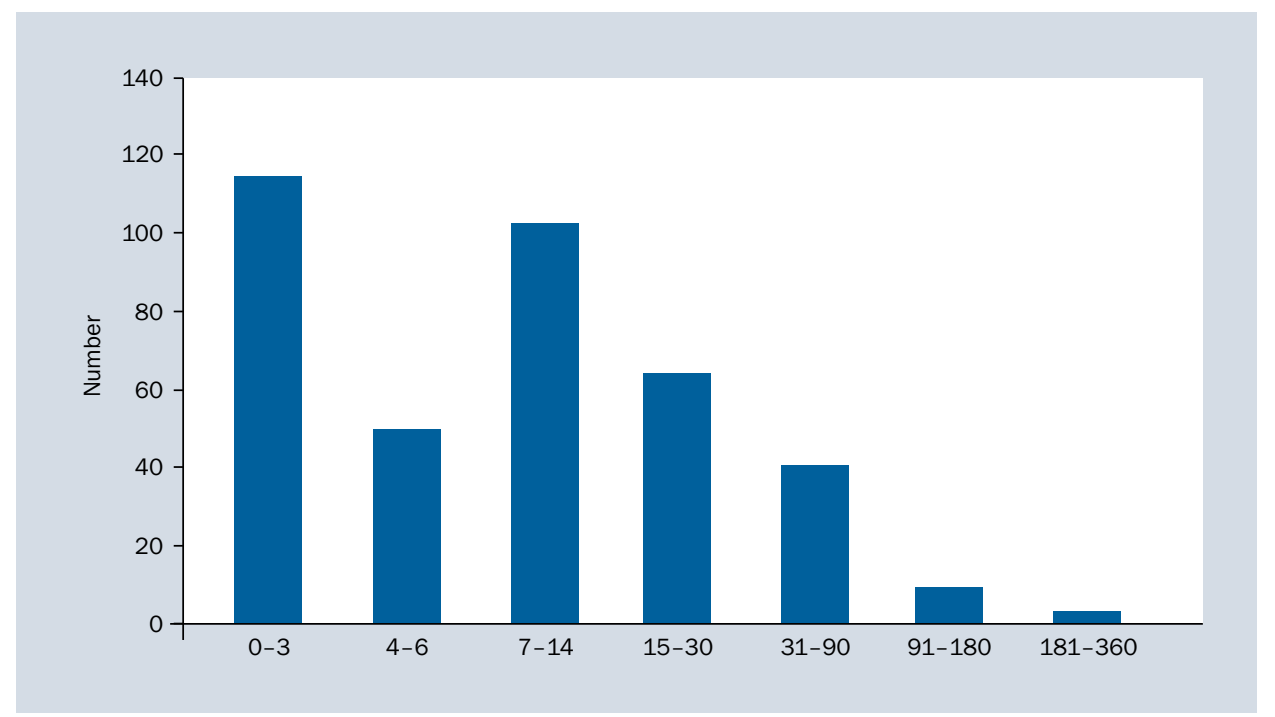

Figure 5. Number of days lost due to injuries $(n=384)$, excluding full pension $(n=1)$ and two fatalities; missing: $n=5$

experience in the same area, as well as wearing some safety equipment (e.g. ice picks) and having experience of getting out of water when falling through sea ice, he drowned and was recovered from the sea bottom later on the same day.

\section{OCCUPATIONAL DISEASES}

There were 18 occupational diseases or suspected occupational disease cases in the insurance claims data of fish farmers and fish farm employees in 1996-2015. Mean age of the subjects was 44.4 years, and 7 out of the total 18 were female. In 5 out of 10 indicated cases (missing information in 8 cases), the person was mainly working in fish processing. In these cases, carpal tunnel syndrome, synovitis/tenosynovitis, allergic contact dermatitis and asthma diagnoses were registered. Predisposition to formalin was indicated in two other asthma cases.

\section{DISCUSSION}

Fishing and aquaculture have had the steepest rise in non-fatal injury incidence rate in the European Union during 2010 to 2015 [8], while agriculture has had the third highest rise. Fish farming involves tasks that resemble both fishing and agricultural farming [9]. In Finland, both have high occupational injury rates: 7.9 injuries/100 person-work-years in fishing [10] and 6.2 to $7.5 / 100$ in agriculture (all recorded injuries) [11]. The corresponding rate for all salary and wage earners ranged from 1.8 in 2013 to 2.9 in 1997 (injuries with 4 or more days of disability) [12].

The injury rates for most industries, including construction work, have shown decreasing trends in Finland [13], but such development cannot be observed in fish farming in the current study. The injury rate of fish farmers and fish farm employees (on average 3.2 injuries per 100 persons working in fish farming, all injuries included) calculated in this study is in the same order as reported for the Norwegian aquaculture in the beginning of the millennium (2.0 to 2.8 for the years 2001-2005) [14]. Since then, there has been a significant decrease in the Norwegian injury rate to around, or below, 1 injury per 100 employed persons. For injuries with four or more days of disability, the calculated injury rate (2.1) corresponds to that of all salaried work force in Finland.

About half of fish farming injuries occurred in coastal areas. However, the incidence rate (injuries per fish farming facility) was highest in the lake district area. The differences may be partially attributed to different production methods and equipment. The difference may also be due to employee numbers per facility; this information was not available in our data sources. It has been suggested that inland aquaculture farms that use more advanced technology are less likely to experience severe injuries [15]. Cultural and social differences between areas may also have a role in safety at work. In earlier studies, Finnish mother tongue (vs. Swedish, which is also an official language in Finland) has been identified as a risk factor for injuries among fishers [16], and farmers [11]. Similar differences have been found in overall mortality across the Finnish population [17]. Åland is predominantly a Swedish speaking area, as are many other coastal municipalities. National statistics show that overall morbidity is lowest in Åland and highest in the eastern areas (Lake district) [18]. These differences based on language and culture may affect the utilisation of services and reporting of injury incidents to insurance systems used in our study. Other risk factors may differ between 
districts as well, but their role is unknown. A systematic review of risk factors for agricultural injury has revealed over 20 significant risk factors, such as regular medication use, hearing loss, sleep deprivation, stress and depression $[19,20]$. Many of these risk factors may apply to injuries in fish farming as well.

Fish farm employees and entrepreneurs in this study had a lower rate of injuries than commercial fishers [10], but the injury characteristics are quite similar. Slipping and falling hazards are often present at workplaces, and they should be taken seriously when designing workplaces and other preventive actions. Attention should also be paid to the protection of upper extremities, which is the most commonly injured body part in our study as well as in corresponding studies in aquaculture in Norway [14] and commercial fishers in Finland [10]. Sprains and strains, wounds, and other superficial injuries generally indicate the need for making fish handling processes more ergonomic and safe.

The age distribution of the fish farmer and fish farm employee population could not be assessed in our data. The mean age of the injured population during injury was 42.0 years, which is clearly lower than that of the commercial fishers (47.6 years, [10]).

The distribution of severity of injuries in fish farming, when assessed by number of days lost due to injury, corresponds fairly well to that of the wage and salary earners in Finland [13]. One common characteristic is the high number of minor injuries ( 0 to 3 days lost): $30.5 \%$ for fish farms and $52 \%$ for all wage and salary earners. This is in contrast with corresponding injury compensation claims data for commercial fishers, where only $1 \%$ of injuries led to the lowest days lost category [10]. The explanation to this difference may lie in differences in typical job statuses: The professional fisher population comprises almost completely of self-employed entrepreneurs while persons occupied in fish farming are for the most part (80\% to $85 \%$ in $2011-2015$ ) full- or part-time wage and salary earners. The median days lost category is the same for both populations ( 7 to 14 days lost), when accounting for injuries with 4 or more days lost.

\section{LIMITATIONS OF THE STUDY}

This study used existing data from insurance and public employment data sources. National employment data were used for estimating the number of employed persons. Occupational accidence insurance (workers' compensation) is mandatory for all employees and entrepreneurs. While these data could be expected to represent total employment and total injury and occupational disease experience in Finland, it is likely that under-reporting of injuries and other biases in estimating both employed persons and injury counts may exist, and their role and direction could not be assessed in this study. It has been widely reported that workers' compensation data under-report actual injury and occupational disease cases [21-24]. On the other hand, compensated claims and self-reported incidents have been compared among farmers in Finland, indicating relatively small level of under-reporting in accident insurance statistics [25].

Occupied person and injury data could not be merged at individual level, and therefore regression methods could not be used to identify injury risk factors or intervention effects. Exact numbers of people occupied in fish farming were not available for the whole observation period, limiting the ability to construct incidence rates for all years. There is also strong variability in working hours and numbers of full- and part-time workers, so only incidents per persons occupied (not per working hours) could be assessed. One reason for this variation is the seasonal nature of the fish farming trade.

Changes in available variables and their classifications, as well as the adoption of the ESAW methods during the observation period, limited some of the analyses to cover only those years with consistent data. Even with careful consideration of source data variables, interpretation errors may remain in constructing the analysis datasets.

\section{CONCLUSIONS}

The injury rate calculated in this study indicates an occupational injury risk in fish farming that corresponds to that of all salaried work force in Finland. The incident rate has not decreased during the observed period which is in contrast to the positive development in other industries, or fish farming in Norway. The expressed intention to grow the Finnish fish farming industry volume stresses the importance of taking actions to reduce injury risks in the trade.

The new approaches in the Finnish aquaculture, growing RAS and offshore farming, will without doubt change occupational safety challenges in future aquaculture. Automation can contribute to reducing the risks, but as it also changes the ways of working, it may introduce new challenges to injury prevention. As the number of fish farms and people working on fish farms is low in Finland, it may be difficult to study health determinants and injury risk factors in detail, or calculate morbidity rates for this population in different geographical or cultural sub-groups. Instead of that, systematic analyses of working processes, technologies and user experiences could result in more detailed information on challenges in injury prevention and produce useful solutions for better safety at work.

\section{ACKNOWLEDGEMENTS}

This study was supported by Natural Resources Institute Finland and The Farmers' Social Insurance Institution (Mela). The Finnish Workers' Compensation Centre (TVK) 
provided the occupational injury and disease claims data, and Statistics Finland the fish farming employment data for this study. The effort of Risto Rautiainen was partially supported by the CDC/NIOSH award U54OH010162 to the Central States Centre for Agricultural Safety and Health at the University of Nebraska Medical Centre.

\section{REFERENCES}

1. Official Statistics Finland: Aquaculture. Natural Resources Institute Finland, Helsinki. Available from. https://stat.luke.fi/en/aquaculture-2017 (cited February 13, 2019).

2. Aquaculture Strategy 2022. Finnish Ministry of Agriculture and Forestry, Helsinki. Available from. https://mmm.fi/en/fisheries/ strategies-and-programmes/aquaculture-strategy (cited February 13, 2019).

3. Standard Industrial Classification 2002. Statistics Finland, Helsinki. Available from. https://www.stat.fi/meta/luokitukset/toimiala/001-2002/index_en.html (cited February 13, 2019).

4. Standard Industrial Classification 2008. Statistics Finland, Helsinki. Available from https://www.stat.fi/meta/luokitukset/toimiala/001-2008/index_en.html (cited February 13, 2019).

5. Official Statistics Finland: Employment. Statistics Finland, Helsinki. Available from . http://www.stat.fi/til/tyokay/index_en.html (cited February 13, 2019).

6. SAS Enterprise Guide v. 7.13 software. SAS Institute Inc., Cary, NC, USA. 2016.

7. TOT 13/07 2007. Kalanviljelijä hukkui pudottuaan jäihin [Fish farmer drowned upon falling through sea ice, in Finnish]. Finnish Workers' Compensation Center (TVK), Helsinki. Investigations of accidents at work 2007:13. Available from. http://totti.tvk.fi/ totcasepublic.view?action=caseReport\&unid=764(cited February 13, 2019.).

8. Overall change in the incidence of non-fatal accidents at work, by NACE division, EU-28, 2010-2015. Eurostat: Accident at work statistics. Available from . https://ec.europa.eu/eurostat/statistics-explained/index.php?title=Accidents_at_work_statistics (cited February 13, 2019).

9. Myers ML. Review of occupational hazards associated with aquaculture. J Agromedicine. 2010; 15(4): 412-426, doi: 10.1080/10599 24X.2010.512854, indexed in Pubmed: 20954037.

10. Kaustell KO, Mattila TEA, Rautiainen RH. Occupational injuries and diseases among commercial fishers in Finland 1996-2015. Int Marit Health. 2016; 67(3): 163-170, doi: 10.5603/IMH.2016.0031, indexed in Pubmed: 27681217.

11. Karttunen JP, Rautiainen RH. Occupational injury and disease incidence and risk factors in Finnish agriculture based on 5-year insurance records. J Agromedicine. 2013; 18(1): 50-64, doi: 10.1080/1059924X.2012.742029, indexed in Pubmed: 23301890.

12. Official Statistics Finland: Wage and salary earners' accidents at work. Statistics Finland, Helsinki. Available from .https://www.stat. fi/til/ttap/2013/ttap_2013_2015-11-27_kat_001_en.html (cited February 13, 2019.).

13. Official Statistics of Finland: Occupational accident statistics. Statistics Finland, Helsinki. Available from. from http://www.stat.fi/til/ ttap/index_en.html(cited February 13, 2019.).

14. Holen S, Utne I, Holmen I, et al. Occupational safety in aquaculture - Part 1: Injuries in Norway. Marine Policy. 2018; 96: 184-192, doi:10.1016/j.marpol.2017.08.009.

15. Martin A. 2016. Risk Factors Associated with Severe Injuries in Inland Aquaculture Farms. Theses and Dissertations. University of Kentucky, College of Public Health. Paper 109. Available from . https:// uknowledge.uky.edu/cph_etds/109/ (cited February 13, 2019.).

16. Kaustell KO, Mattila TEA, Hurme T, et al. Predictors for occupational injuries and diseases among commercial fishers in Finland 1996-2015. Int Marit Health. 2017; 68(4): 196-202, doi: 10.5603/ IMH.2017.0037, indexed in Pubmed: 29297570.

17. Sipilä $P$, Martikainen P. Language-group mortality differentials in Finland in 1988-2004: assessment of the contribution of cause of death, sex and age. Eur J Public Health. 2009; 19(5): 492-498, doi: 10.1093/eurpub/ckp074, indexed in Pubmed: 19502514.

18. Regional morbidity differences must be considered in organizing services. National Institute for health and welfare 2016, Helsinki. Available from .https://thl.fi/en/web/thlfi-en/-/regional-morbidity-differences -must-be-considered-in-organising-services (cited February 13, 2019).

19. Jadhav R, Achutan C, Haynatzki G, et al. Risk Factors for Agricultural Injury: A Systematic Review and Meta-analysis. J Agromedicine. 2015; 20(4): 434-449, doi: 10.1080/1059924X.2015.107545, indexed in Pubmed: 26471953.

20. Jadhav R, Achutan C, Haynatzki G, et al. Review and Meta-analysis of Emerging Risk Factors for Agricultural Injury. J Agromedicine. 2016; 21(3): 284-297, doi: 10.1080/1059924X.2016.117961, indexed in Pubmed: 27088816.

21. Shannon HS, Lowe GS. How many injured workers do not file claims for workers' compensation benefits? Am J Ind Med. 2002; 42(6): 467-473, doi:10.1002/ajim.10142, indexed in Pubmed: 12439869.

22. Koehoorn M, Tamburic L, Xu F, et al. Characteristics of work-related fatal and hospitalised injuries not captured in workers' compensation data. Occup Environ Med. 2015; 72(6): 413-420, doi: 10.1136/ oemed-2014-102543, indexed in Pubmed: 25713157.

23. Leibler JH, Perry MJ. Self-reported occupational injuries among industrial beef slaughterhouse workers in the Midwestern United States. J Occup Environ Hyg. 2017; 14(1): 23-30, doi: 10.1080/1 5459624.2016.1211283, indexed in Pubmed: 27715500.

24. Fan Z, Bonauto DK, Foley MP, et al. Underreporting of work-related injury or illness to workers' compensation: individual and industry factors. J Occup Environ Med. 2006; 48(9): 914-922, doi: 10.1097/01. jom.0000226253.54138.1e, indexed in Pubmed: 16966958.

25. Eskelinen S, Notkola V, Tupi K. Miten kattavasti viljelijät ilmoittavat työtapaturmistaan? [How consistently do farmers report their injuries?]. Farmers Social Insurance Institution, Espoo. Publication 2/89. 1989(ISBN 951-9402-56-X): Finnish-54. 